\title{
Motivos para escribir un libro. A propósito de mis Angelitos Salvados
}

\author{
Jorge Jiménez de la Jara ${ }^{1 *}$
}

Fecha de envío: 20 de Julio de 2012 - Fecha de aceptación: 3 de 0ctubre de 2012

Ars Medica tiene el honor de compartir con sus lectores una reflexión escrita por el Profesor Jorge Jiménez de la Jara acerca de las motivaciones que tuvo para escribir el libro Angelitos Salvados (Ugbar Editores, Santiago, 2009), en cuyas páginas repasa los antecedentes del gran proyecto social que implicó la lucha contra la mortalidad infantil durante el siglo XX en Chile. En su destacada trayectoria como Médico Pediatra (Pontificia Universidad Católica de Chile y Universidad de Chile) y Magíster en Salud Pública (Johns Hopkins University), el Profesor Jiménez ha ocupado importantes cargos, destacando los de Ministro de Salud (1990-1992), Embajador de Chile en Italia (1995-1998) y Presidente del Consejo Ejecutivo de la Organización Mundial de la Salud (1998-2000). Desde 1998 se desempeña como Profesor Asociado del Departamento de Salud Pública de la Pontificia Universidad Católica de Chile, lugar donde realiza labores de investigación y docencia.

Hay algunos proyectos que toman tiempo, otros que salen rápidamente después de gestaciones inaparentes. No es el caso de los libros, no fue mi caso para escribir sobre una parte de la historia personal y profesional que he vivido como especialista en salud infantil. Me tomó varios años pensar cómo recopilar los antecedentes, cómo expresar las vivencias, cómo tratar de convencerme y convencer que esa epopeya de la salvación de seres inocentes era una historia heroica, espiritual y trascendente que merecía ser contada para no ser olvidada. Había llamas interiores calentando la caldera que generaba energía positiva. Ser hijo y tener un padre ejemplar, tener hijos y criarlos en familia con su madre, haber perdido un hijo y nunca haberlo llorado lo suficiente, haber visto a tantos niños nacer, crecer y desarrollarse como maravillas para ver la alegría de sus progenitores, sentir y sufrir el dolor y la muerte de tantos pequeños por condiciones injustas y evitables.
La pediatría social de mis maestros me fue llenando la mente y la experiencia con hechos, anécdotas, instrumentos, métodos de investigación y acción médica y social, modelos de acción social trascendente y solidaria. Tenía una historia que contar.

En principio traté de hacer un relato lo más "evidence-based" posible para seguir la moda de la racionalidad que nos inunda. Muchos datos, cifras, estadísticas llegaron a mi disco duro. Ensayé algunas correlaciones para demostrar lo importante que era nuestro papel como médicos sociales y sentí que había logrado algo bueno. Sin embargo, al consultar con mi editora -indispensables personajes- me di cuenta de que faltaba esa emoción y afecto que le da la fuerza a los relatos. Y recordé decenas de ellas, desde mis propios recuerdos infantiles de la mano de mi padre recorriendo basurales y poblaciones callampas en San Bernardo y el río Maipo, hasta las mías propias como Ministro de Salud conteniendo un brote de sarampión inminente cuarenta años después.

Demoré más de cuatro años en darle esa forma de relato científico pero emocionado. Recurrí a la imagen conmovedora del Velorio del Angelito y me dije que entre miles habíamos salvado muchos Angelitos de la muerte y la enfermedad. Que esas imágenes de la película Largo Viaje de Kaulen, la pintura decimonónica de Manuel Antonio Caro, el tapiz y la canción de Violeta Parra no podían ser olvidadas ya que reflejaban una etapa que debíamos resaltar para entender lo que vivimos hoy, en 2011, con miles de jóvenes en las calles pidiendo educación. Ya no piden vida, piden ser mejor educados y mejores personas. El "bono demográfico" que se agita en nuestras calles y necesariamente provoca la revolución que necesitamos, la del conocimiento con equidad de acceso y resultados garantizados para seguir creciendo como sociedad.

1) Departamento de Salud Pública, Facultad de Medicina de la Pontificia Universidad Católica de Chile

*Autor de Correspondencia: jjimenez@med.puc.cl 
Jiménez 2012

La prestigiosa revista The Lancet (Astudillo, 2011) me ha dado dos páginas para comentar al mundo el valor de Angelitos Salvados y me ha abierto la posibilidad de transformarlo en un texto en idioma universal: inglés y digital. El nuevo desafío para mis angelitos chilenos sigue valiendo la pena.

\section{Referencias}

Astudillo O. (2011). Saving Chile's angelitos. The Lancet 378, 1771-1772. 